\title{
TRACKING OF EATING DISORDERS SYMPTOMS AND EVALUATION OF BODY IMAGE PERCEPTION IN BALLERINAS.
}

\author{
Heloisa Castanheira Sto. André*, Fabiana Braga Benatti.
}

\begin{abstract}
A cross-sectional study was conducted with 14 participants from 18 to 30 years old who dance classical ballet at academies in the city of Campinas/SP, Brazil; in order to analyze the presence of symptoms of eating disorders development and the body image perception and (in) satisfaction in classical ballet practitioners. Quantitative data were generated through questionnaires (BITE, BES, EAT-26 and Stunkard's Scale), and qualitative data through focus groups. Approximately half of the dancers had symptoms of eating disorders as well as dissatisfaction with their body image, data that are possibly related to the fact that the participants do restrictive diets on a recurring basis in order to achieve a leaner body than they consider healthy. In addition, few participants had a nutritional follow-up, suggesting a low participation of qualified professionals in this sport, which would be extremely important to avoid the development of eating disorders symptoms, besides helping to increase sports performance and improve dancers life quality.
\end{abstract}

\section{Key words:}

Classic Ballet. Eating Disorders. Body Image.

\section{Introduction}

Some recent studies have shown that the requirement of maintaining an aesthetic pattern among dancers is greater than among the general population, which seems to distort the body image and lead to food vices. Besides that, studies also pointed out that prevalence of Eating Disorders (ED) is higher in athletes than non-athletes.

The main objective of this study was to evaluate the presence of symptoms for eating disorders development, and the perception and (in) satisfaction with body image in classical ballet dancers.

\section{Results and Discussion}

A cross-sectional study was carried out with 14 participants from 18 to 30 years old who dance classical ballet at academies in the city of Campinas/SP, analyzing these following variables: (1) the presence of eating disorders symptoms; and (2) perception and (in) satisfaction with body image. Quantitative data were generated through specific questionnaires (Bulimic Investigatory Test, Binge Eating Scale, Eating Attitude Test-26 and Stunkard's Scale) and, additionally, these items were assessed qualitatively through focus groups.

To evaluate the focus groups, six themes were selected to be explored, constituting a codebook (Usual Feeding, Atypical Feeding, Eating Attitudes, Body Image, External Perceptions and Rehearsals and Career Goals). The sentences of the groups were enumerated and analyzed by two researchers separately, following the codebook rules. Subsequently, the data of each researcher were tabulated and compared. To verify the reliability among the evaluators, a Kappa coefficient was performed using GraphPad QuickCalcs online software.

The quantitative results are consistent with the literature, since $50 \%$ of the dancers presented bulimic symptoms (14.29\% had a significant risk index), $7.14 \%$ showed symptoms of moderate binge eating and $14.29 \%$ of general eating disorder symptoms. On the Stunkard scale, $50 \%$ of the sample was dissatisfied with the current body shape, and $57.1 \%$ considered the desirable body shape to be leaner than that considered healthy. During the focus groups, some disturbing dietary attitudes were detected, such as the frequent performance of restrictive diets and weight loss strategies, the presence of binge eating episodes, linked to guilty feelings, the habit of classifying foods as good and bad, among others. On the other hand, important opinions about body image were also detected, when analyzing their bodies in a daily basis, the participants considered themselves satisfied, however, when analyzing them in a "classic ballet" context, they would change some things in their bodies.

\section{Conclusions}

Approximately half of the dancers had symptoms of eating disorders in addiction to dissatisfaction with their body image, data that are possibly related to the fact that the participants do restrictive diets on a recurring basis in order to achieve a leaner body than they consider healthy. In addition, few participants had a nutritional follow-up, suggesting a low participation of qualified professionals in this sport, which would be extremely important to avoid the development of eating disorders symptoms, besides helping to increase sports performance and improve dancers life quality.

\footnotetext{
${ }^{1}$ DENOMA, J.M.H.; SCARINGI, V.; GORDON, K.H.; VAN ORDEN, K.A.; JOINER, T.E. Eating disorder symptoms among undergraduate varsity athletes: club athletes, independent exercisers and nonoexercises. International Journal of Eating Disorders, Hoboken, v.12, n.1, p.47-53, 2009

2 PINTO, Ana Jéssica et al. Eating Attitudes and Body Image Perception of elite male Artistic Gymnasts: A Mixed Method. São Paulo, 2019.

3PHILIPPI, Sonia Tucunduva et al (Org.). Nutrição e transtornos alimentares: Avaliação e Tratamento. Barueri: Manole, 2011.521 p.

REIS, Nycolle Martins et al. Imagem corporal, estado nutricional e sintomas de transtornos alimentares em bailarinos. Revista Brasileira de Atividade Física \& Saúde, Pelotas/RS, v. 18, n. 6, p.763-781, Nov, 2013

SUNDGOT-BORGEN J, KLUNGLAND TM, Prevalence of eating disorders in elite athletes is higher than the general population. Clin J Sport Med, v.14, p.25-32, 2004
} 